\title{
Effectiveness Of Incision Wound Healing Of Pandanus Amaryllifolius Roxb In Wistar Rats
}

\author{
Muna Soraya Putri ${ }^{1}$, Ermi Girsang ${ }^{2}$, Linda Chiuman ${ }^{3}$, Chrismis Novalinda Ginting ${ }^{4 *}$ \\ 1,2,3,4 Faculty of Medicine, Universitas Prima Indonesia, Medan, Indonesia \\ * Corresponding author: \\ Email: chrismisnovalindaginting@unprimdn.ac.id
}

\begin{abstract}
.
The incision is a condition of tissue discontinuity that is commonly encountered with the risk of prolonged healing time, imperfect wound healing, infection, etc. Assessment of the wound healing activity of the incision is the purpose of this research, which includes an examination of wound contraction, the thickness of collagen fibers, and the number of new blood vessels formation. In total, 25 rats will be divided into 5 test groups, each consisting of 5 rats; the control group (cream base treated), standard group (Povidone Iodine), followed by the treated group with 10\%, 20\%, and $30 \%$ pandan leaf extract ointment. The preliminary screening of phytochemical analysis showed the presence of alkaloids, saponins, flavonoids, tannins, triterpenoids, and steroids and glycosides, with the total content of phenols and flavonoids from the ethanolic extract of Pandan Wangi is 20.95 GAE mg/gram extract, and 23.57 TAE mg/gram extract. Wound contraction examination result showed a significant difference between the treatment groups on day 16 and a sign the pairs of groups after being given the ointment with each concentration $(p<0.05)$, especially in the group with $30 \%$ fragrant leaves extract and the standard group. Examination of new blood vessels showed a significant difference $(p<0.05)$, especially with $30 \%$ of the leaves extract ointment. There was also a significant difference in collagen density in the group given pandanus ethanol ointment, especially at the $30 \%$ pandanus extract content against the group that was only given the ointment base. This research strongly suggests that the fragrant pandan leaf extract ointment is effective in healing incisional wounds and promises the potential for further studies on the pharmacological aspects.
\end{abstract}

Keywords: Pandanus extract, Ointment, Wound Healing, Angiogenesis, Collagen fiber

\section{INTRODUCTION}

One of the mechanical damage to the skin is the occurrence of tissue discontinuities caused by cuts, lacerations, friction wounds (abrasions), pulling wounds (avulsions), penetrating wounds (penetration), bites, burns, and surgery. Wounds that occur on the skin will stimulate wound healing that will involve various substrates cells and processes that are physiological processes that include the hemostasis phase characterized by vasoconstriction, primary hemostasis, and secondary hemostasis (Rodrigues et al., 2019).The complex process of wound healing, especially incisions, is still one of the challenges in health, considering the number of cases and treatment methods developed in the current era of globalization. Many studies on wound healing have used natural ingredients such as herbal plants and fruits to be formulated as preparations to help wound healing. A traditional herbal which can be considered is the fragrant pandan leaf (Pandanus amaryllifolius Roxb). Fragrant pandan leaves have 2-acetyl-1-pyrroline (ACPY) compounds and oxygenation degradation of yellow carotenoid pigments (Silalahi, 2018). In addition to these compounds, secondary metabolites such as alkaloids, flavonoids, phenols, saponins, and terpenoids in the fragrant pandan leaf make it a traditional diabetes treatment and help the wound healing process. Ningrum et al. (2015) stated that pandan leaves contain carotenoid and xanthophyll compounds. Carotenoids, especially carotene, are precursors of norisoprenoids. Carotenoids have long been known as antioxidant compounds to protect against various degenerative diseases such as cancer, coronary heart disease, or diseases related to aging.

\section{METHODS}

\subsection{Materials}

The ingredients in this study were fragrant pandan leaves, aquadest, lanolin, solid paraffin, Cetostearyl alcohol, white vaseline, gauze, oil paper, filter paper, Povidone Iodine, rat pellets, Neutral Buffered Formalin (NBF) 10\%, hematoxylin \& eosin dye, and aquadest. The tools used are digital scales, 
caliper, filter, lumping digital camera, microtome (Leica RM2235), maceration vessel, knife, rotary evaporator, water bath, gel container, stirring rod, object-glass, cover glass, organ storage container.

\subsection{Extract Preparation}

The fragrant leaves were washed using running water to make pandanus extract and then cut into small pieces and dried for several days at room temperature. The dried leaves were mashed using a blender machine and put into a maceration vessel. The vessel is filled with 70\% ethanol in a ratio of 1:6 (Simplified: solvent). Furthermore, the vessel is closed and left for five days in a place protected from the sun and damp, stirring occasionally. When it has been five days, then filtered and re-extracted the dregs, done one time to get more extract. Then the extract was concentrated with a vacuum rotary evaporator at a temperature of $60^{\circ} \mathrm{C}$ and evaporated through heating until a thick extract was obtained (Aini, 2016; Nagar, 2016; Sugihartini, 2017). After extraction, preliminary phytochemical tests were carried out (Buckley 1966; Richardson and Harborne 1985; Suman et al. 2016).

Ointment of pandanus extract has been prepared with the following formulation:

Table 1. Ointment Formulation

\begin{tabular}{lllll}
\hline \multicolumn{1}{c}{ Composition } & $\begin{array}{l}\text { Ointment } \\
\text { Base }\end{array}$ & $\begin{array}{l}\text { Pandanus } \\
\text { Ointment } \\
\mathbf{1 0 \%}\end{array}$ & $\begin{array}{l}\text { Pandanus } \\
\text { Ointment } \\
\mathbf{2 0 \%}\end{array}$ & $\begin{array}{l}\text { Pandanus } \\
\text { Ointment } \\
\mathbf{3 0 \%}\end{array}$ \\
\hline Pandanus extract (ml) & - & $1 \mathrm{ml}$ & 6 & 9 \\
Stearic acid (g) & 15 & 15 & 15 & 15 \\
Cetyl alcohol (g) & 6 & 6 & 6 & 6 \\
Potasium hydroxide (g) & 0.7 & 0.7 & 0.7 & 0.7 \\
Methyl Paraben (g) & 0.3 & 0.3 & 0.3 & 0.3 \\
Propyl Paraben (g) & 0.06 & 0.06 & 0.06 & 0.06 \\
Glycerine (g) & 5.0 & 5.0 & 5.0 & 5.0 \\
Propylene glycol (g) & 3.0 & 3.0 & 3.0 & 3.0 \\
Aquadest (g) & Add 100 & Add 100 & Add 100 & Add 100 \\
\hline
\end{tabular}

\subsection{Animal Experiment}

The experimental animal is Wistar rats with a sample size of 25 white male rats, divided into 5 test groups. Each test group consists of 5 white rats calculated by the Federer formula. All rats were placed in animal cages with the same size and pellet food for rats in all treatment groups, with a temperature of 2427oC, a 12-hour morning cycle, and a 12-hour night cycle. All groups are acclimatized for seven days. On the eighth day, they will be shaved using a razor before wounding; experimental wounds are performed under sterile conditions under anesthesia using ketamine $(75 \mathrm{mg} / \mathrm{kg}$ i.m) which had previously been fasted. The incision wound was made on the Rat's back tail and pulled up with a length of $6 \mathrm{~cm}$ and a depth of 2 $\mathrm{mm}$. Then all groups of rats will be treated in topical application of Povidone Iodine, ointment base, and $10 \%, 20 \%, 30 \%$ fragrant pandan leaf extract ointment two times a day for 16 days. Then at the end of the study, the rats will be euthanized for taking skin specimens. (Jeong, 2017; Ersel, 2016; Saifudin, 2020; Angkasa, 2019).

Experimental rats were divided into five groups; Control (treated with ointment base), Standard (treated with Povidone-Iodine), PDW 10\% (treated with Pandanus extract 10\%), PDW 20\% (treated with Pandanus extract 20\%), PDW 30\% (treated with Pandanus extract 30\%). The examination of the effectiveness of the incision was carried out on days $0,4,8,12,16$. The evaluated aspects of the incision wound healing activity included wound contraction and histopathological examination (Asrade et al., 2020; Nagar et al., 2016). Wound contractions were measured by measuring the diameter of the wound using a caliper every four days, then Wound contractions were calculated using the following formula (Asrade et al., 2020; Nagar et al., 2016):

Wound contraction $(\%)=($ initial wound size - wound size at specific days) / (wound size at specific days) $\times 100 \%$. 
At the end of the study, the test animals will be euthanized using a high dose of ether solution by inhalation. The back area where the skin will be taken will be shaved first from the hair that grows back. Skin samples were taken with a thickness of $\pm 3 \mathrm{~mm}$ to the subcutaneous area along the $2.5 \mathrm{~cm}$. The skin sample was then fixed with Neutral buffered formalin or $10 \%$ NBF solution and left for \pm 48 hours. This block of skin tissue would be incised again using a microtome thickness of $5 \mathrm{~m}$ to prepare histopathological reading preparations. Samples were then stained with Hematoxylin \& Eosin (H\&E) for the histological examination to observe the formation of new blood vessels and the density of collagen fibers. (Nanda et al, 2017; Nagar et al, 2016). Histological observation criteria for collagen and angiogenesis followed the previous studies (Shakya et al., 2016; Nasiri et al., 2015).

\subsection{Statistical Analysis}

The statistical analysis used in this study was the One-Way ANOVA test, followed by a post-hoc LSD test. The Shapiro-Wilk test was performed before the ANOVA test to determine the normality. The Levene test was performed to examine the homogeneity of two or more groups of sample data originating from the same population (homogeneous). Then the histopathological changes data were analyzed using the Kruskal-Wallis test followed by the Mann-Whitney- $U$ difference test because there was a significant difference with a significant degree of $\mathrm{p}<0.05$.

\section{RESULTS}

\subsection{Phytochemical Analysis}

The phytochemical screening of fragrant pandan leaves extracted using ethanol showed the presence of alkaloids, saponins, flavonoids, tannins, triterpenoids, steroids, and glycosides - the details as shown in Table 2 .

Table 2. Preliminary Screening of Phytochemistry

\begin{tabular}{lll}
\hline Secondary Metabolites & Methods & Interpretation \\
\hline Alkaloid & Bouchardart & + \\
& Maeyer & - \\
& Wagner & - \\
& Dragendorff & + \\
\hline Triterpenoid and Steroid & Salkowsky & - \\
& Lieberman-Burchard & + \\
\hline Saponin & Aquadest + Alcohol $96 \%$ & + \\
\hline Flavonoid & $\mathrm{FeCl}_{3} 5 \%$ & + \\
& $\mathrm{Mg}_{(\mathrm{s})}+\mathrm{HCl}(\mathrm{p})$ & + \\
& $\mathrm{NaOH} 10 \%(\mathrm{p})$ & - \\
\hline Tannins & $\mathrm{H}_{2} \mathrm{SO}_{4(\mathrm{p})}$ & + \\
\hline Glycoside & $\mathrm{FeCl}_{3} 1 \%$ & + \\
\hline
\end{tabular}

The analysis was then continued by determining the total content of phenols and flavonoids, as shown in Table 3.

Table 3. Total Phenols and Flavonoids content

\begin{tabular}{cc}
\hline Compounds & Total-Content \\
\hline Phenols (GAE mg/ gram extract) & $20.95 \pm 0.39$ \\
Flavonoids (QE mg/gram extract) & $23.57 \pm 0.43$ \\
\hline
\end{tabular}

GAE: Gallic Acid Equivalent; QE: Quercetin Equivalent.

3.2 Physical Characteristics of Ointment

The homogeneity test carried out on all ointment preparations gave homogeneous results for each preparation based on the uniformity of color and the absence of lumps and granules. The $\mathrm{pH}$ data showed that the $\mathrm{pH}$ values of all ointment preparations ranged from 5.62 to 5.79 and had met the requirements for a safe $\mathrm{pH}$ value for the skin, namely $\mathrm{pH} 5.5$ to 6.0. 


\subsection{Wound Contraction Analysis}

Wound contraction as one of the incision wound healing parameters was analyzed according to the normality of the data from each measurement time. The data will be determined for normality using ShapiroWilk and Levene's homogeneity test. Then analyzed by One Way ANOVA test at $95 \%$ confidence level ( $\mathrm{p}<$ 0.05 ) with $1=0.05$. Further analysis was carried out using Post Hoc Tukey HSD (Honestly Significance Different) to determine the level of difference in the influence of each group.

Table 4. Normality Test of Wound Healing Effectivity of Pandanus Ointment

\begin{tabular}{lcl}
\hline Parameter & p-value & Interpretation \\
\hline Wound contraction K (-) & 0.060 & Normal \\
Wound contraction Povidone Iodine & 0.064 & Normal \\
Wound contraction PDW 10\% & 0.107 & Normal \\
Wound contraction PDW 20\% & 0.210 & Normal \\
Wound contraction PDW 30\% & 0.132 & Normal
\end{tabular}

From the data in Table 4, it can be seen that the wound contraction data in the control group, Povidone Iodine, $10 \%, 20 \%$, and $30 \%$ fragrant pandanus, were usually distributed. So that the analysis was continued with the One Way ANOVA test then followed by the Post Hoc Test. The homogeneity test by Levene's method showed that the sig value was $0.070>0.05$. It can be concluded that the data was homogeneous. They qualified for the One Way ANOVA test.Based on the ANOVA test results with a Sig value of $0.070<0.05$, it can be concluded that there are differences between the means in all treatment groups. To see significant differences in each group, the LSD test was performed, as shown in Table 5.

Table 5. Least Significant Difference (LSD Test of Wound Healing Effectivity

\begin{tabular}{cccccc}
\hline Group & $\begin{array}{c}\text { Control (K- } \\
\text { ) }\end{array}$ & $\begin{array}{c}\text { Standard } \\
\text { (PI) }\end{array}$ & $\begin{array}{c}\text { PDW } \\
\mathbf{1 0}\end{array}$ & PDW 20 & PDW 30 \\
\hline Control (K-) & - & $<0.001^{*}$ & 0.407 & 0.097 & $<0.001^{*}$ \\
$\begin{array}{c}\text { Standard } \\
\text { (PI) }\end{array}$ & $<0.001^{*}$ & - & 0.072 & 0.331 & 0.626 \\
PDW 10 & 0.407 & 0.072 & - & 0.400 & $<0.001^{*}$ \\
PDW 20 & 0.097 & 0.331 & 0.400 & - & 0.146 \\
PDW 30 & $<0.001^{*}$ & 0.626 & $<0.001^{*}$ & 0.146 & -
\end{tabular}

*) significant value $(\mathrm{p}>0.05)$

The results of the Least Significant Difference (LSD) test on wound contraction incisions in rats shown in Table 8 show that there were significant differences between the pairs of groups after being given the ointment with each concentration, namely the difference in wound length in the negative control group (K-) which was only given ointment base with the group that was given Povidone Iodine (PI) and the group that was given pandan fragrance ointment with a concentration of $30 \%$ (PDW 30), while there was no significant difference between (K-) and the group that was given pandan fragrance ointment with a concentration of 10\% (PDW 10). and 20\% (PDW 20). Then there was a significant difference between the group (PDW 10) and the group (PDW 30). In the group (PDW 20), there were no significant differences in all treatment groups. The group (PDW 30) had a significant difference in the (K-) and (PDW 10) groups, while the Povidone Iodine and (PDW 20) groups did not show a significant difference. 


\subsection{Histopathology Analysis}

In addition to wound contraction, other parameters that are also evaluated in assessing wound healing are the formation of new blood vessels and the density of collagen fibers through histopathological examination with Hematoxylin \& Eosin (H\&E) staining. The formation of new blood vessels based on angiogenesis is shown in Figure 1.

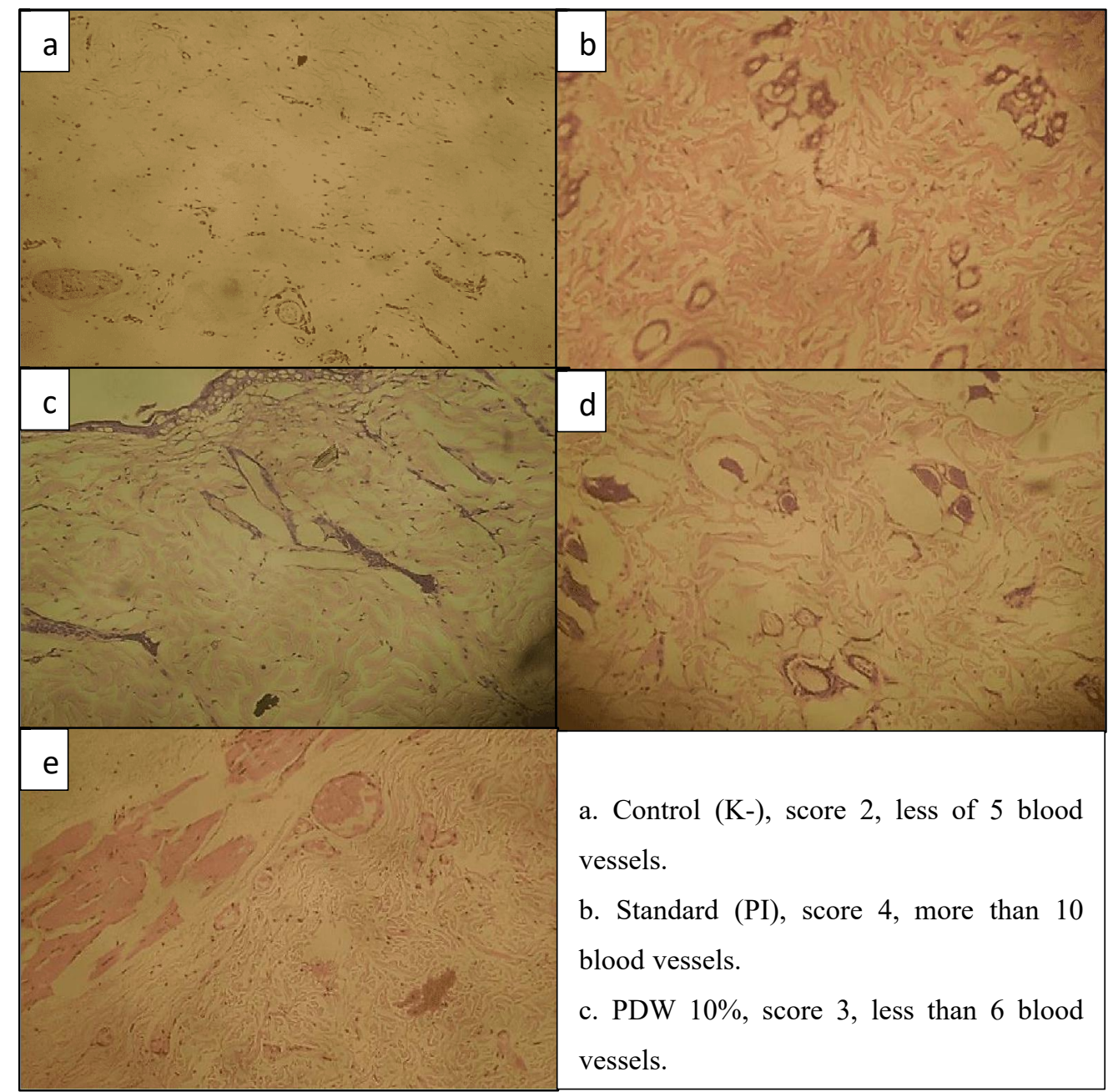

Fig 1. Formation of new blood vessels of Control (a), Standard (b), PDW 10\% (c), PDW 20\% (d), and PDW 30\% (e),

Furthermore, the statistical analysis using Mann Whitney-U on the new blood vessels formation is shown in Table 6.

Table 6. Mann Whitney-U Test of the New Blood Formation

\begin{tabular}{cccccc}
\hline Group & Control (K-) & Standard (PI) & PDW 10 & PDW 20 & PDW 30 \\
\hline Control (K-) & - & $<0.05^{*}$ & $<0.05^{*}$ & $<0.05^{*}$ & $<0.05^{*}$ \\
Standard (PI) & $<0.05^{*}$ & - & $<0.05^{*}$ & 0.824 & 0.276 \\
PDW 10 & $<0.05^{*}$ & $<0.05^{*}$ & - & $<0.05^{*}$ & $<0.05^{*}$ \\
PDW 20 & $<0.05^{*}$ & 0.824 & $<0.05^{*}$ & - & $<0.05^{*}$ \\
PDW 30 & $<0.05^{*}$ & 0.276 & $<0.05^{*}$ & $<0.05^{*}$ & - \\
\hline
\end{tabular}

*) significant value $(\mathrm{p}<0.05)$

In the group of control (K-) given the ointment base to the group given Povidone-iodine (PI), the group given the pandan fragrance extract ointment 10\% (PDW10), 20\% (PDW20), and 30\% (PDW30) showed a significant difference $(\mathrm{p}=0.05)$. This shows that there are differences in blood vessel formation between the K(-) group and the Povidone (PDW10), (PDW20), and (PDW30) groups. The (K-) and (PDW10) groups showed a significant difference in the Povidone group. It can be interpreted that there are 
differences in the formation of blood vessels. Meanwhile, there was no significant difference in the Povidone group (PDW20) and (PDW30). In the group (PDW10) against Povidone, (K-), (PDW20), and (PDW30) ) showed a significant difference. In the (PDW20) and (PDW30) against (K-) groups, (PDW10) showed a significant difference. In contrast, the groups (PDW20) and (PDW30) against Povidone showed no significant difference. It can be interpreted that there is no difference in the formation of blood vessels.

Based on the criteria for observing the histological picture of collagen density, the results are shown in Figure 2.

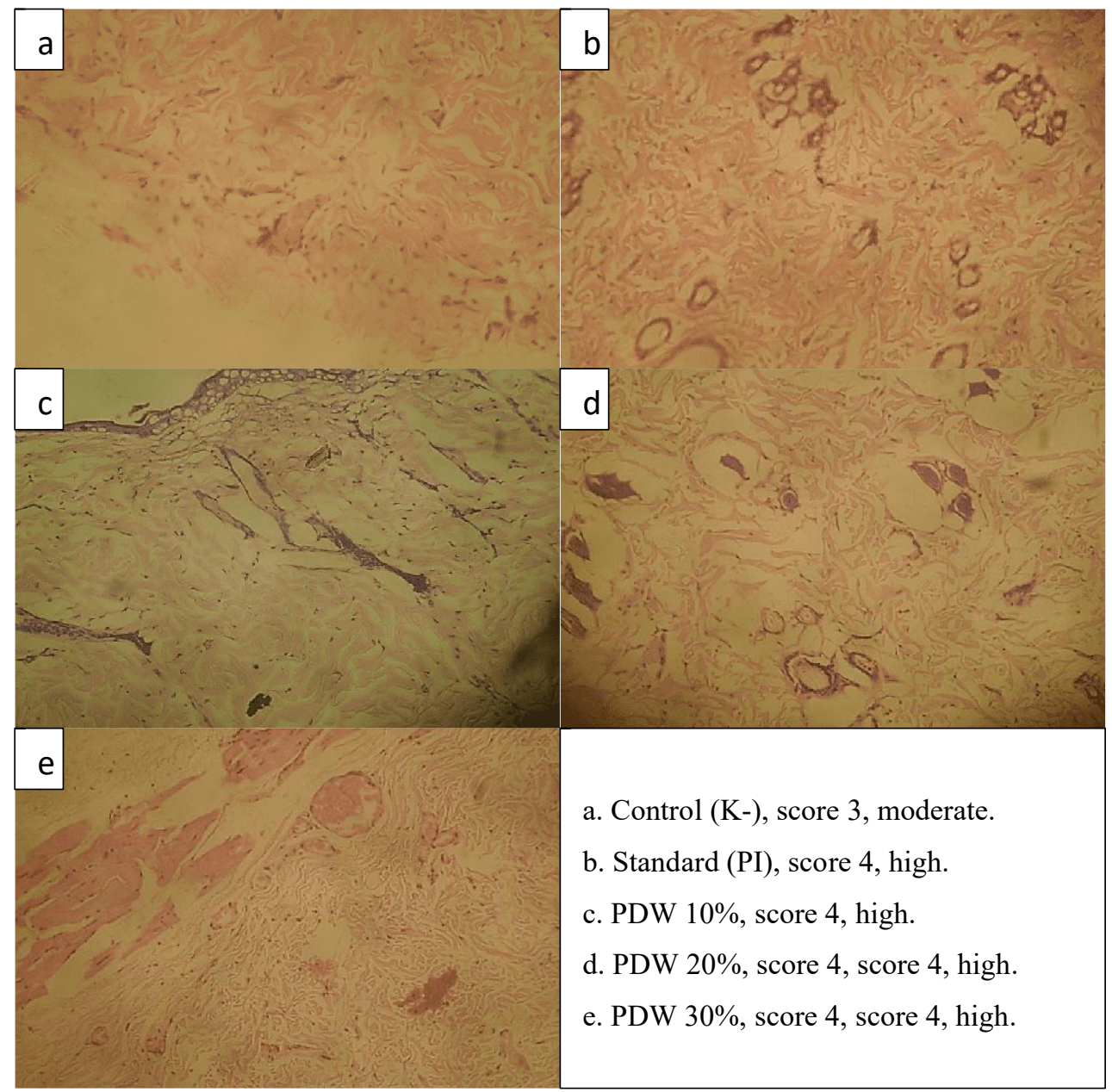

Fig 2. Collagen Density of Control (a), Standard (b), PDW 10\% (c), PDW 20\% (d), and PDW 30\% (e)

In the group (K-) given the ointment base to the group given Povidone-iodine (PI), the group given the pandan fragrance extract ointment 10\% (PDW10), 20\% (PDW20), and 30\% (PDW30) showed a significant difference $(\mathrm{p}=0.05)$. This indicates that there is a difference in collagen density between the K() group and the Povidone (PDW10), (PDW20), and (PDW30) groups. Meanwhile, in the Povidone group (PDW10), (PDW20), and (PDW30), there was no significant difference. It can be interpreted that there is no difference in collagen density between the Povidone (PDW10), (PDW20), and (PDW30) groups.

Table 7. Mann Whitney-U Test of the Collagen Density

\begin{tabular}{cccccc}
\hline Group & Control (K-) & Standard (PI) & PDW 10 & PDW 20 & PDW 30 \\
\hline Control (K-) & - & $<0.05^{*}$ & $<0.05^{*}$ & $<0.05^{*}$ & $<0.05^{*}$ \\
Standard (PI) & $<0.05^{*}$ & - & 0.108 & 0.190 & 0.200 \\
PDW 10 & $<0.05^{*}$ & 0.091 & - & 0.091 & 0.071 \\
PDW 20 & $<0.05^{*}$ & 0.190 & 0.091 & - & 0.140 \\
PDW 30 & $<0.05^{*}$ & 0.200 & 0.071 & 0.140 & - \\
\hline
\end{tabular}

*) significant value $(\mathrm{p}<0.05)$ 


\section{DISCUSSION}

The number of compounds in fragrant pandan leaves (Pandanus amaryllifolius Roxb) plays a role in wound healing. Some theories state that flavonoids are known to play a role in capturing free radicals or can function as natural antioxidants. The antioxidant activity allows flavonoids to capture or neutralize free radicals to repair damaged tissue. (Lolok, et al 2020; Dewanti, et al 2017). In this study, it was found that there was a reasonably good flavonoid content from the extraction method that had been carried out so that it was able to affect the healing of cuts in rats which can be seen in the results of the research parameters that have been described, this is also reinforced by research conducted by Dewi et al. (2019) in pandan leaf plants which from the results of his research showed the optimum flavonoid content with a long extraction time of 40 minutes which was $7.1 \%$, which means that an increase in temperature and extraction time will affect the compounds in solution, the extraction temperature is too high and the extraction time is too high. The length of time and the optimum time limit can cause the loss of compounds in solution due to evaporation; if the extraction temperature is too low, it will cause not all active compounds to be extracted from the material and result in low active compounds obtained (Dewi et al., 2019). Wound healing on fragrant pandan leaves, which contain flavonoids in powder mask preparations, also shows the ability to inhibit skin damage, maintain normal skin regeneration, and play an essential role in absorbing and neutralizing free radicals.

On the other hand, the saponins contained in the fragrant Padan leaves were found with the formation of foam on phytochemical examination, also contributing as antioxidants in the formation of skin collagen tissue which is needed in the formation of new tissue in wound healing, maintaining the balance of oil and skin moisture. The ability of flavonoids in Pandanus amaryllifolius Roxb to scavenge free radicals was also found in the reduced histological changes in the liver induced by carbon tetrachloride (CC14) compared to the group that did not receive treatment with Pandanus amaryllifolius. Shameenii A. et al. (2021) explained that the antioxidant and free radical scavenging properties of Pandanus amaryllifolius could protect the liver from extreme damage caused by carbon tetrachloride (CC14). At the same time, research related to fragrant pandan leaf extract can inhibit the cytotoxic effect of the Head And Neck Squamous Cell Carcinoma Cell Line (HNSCC cell line; HN31) (Suwannakul, 2018). This may be due to the fragrant pandan leaf extract, which shows a high content of phenolics, flavonoids, carotenoid compounds, and xanthophylls.Carotenoids, especially carotene, are precursors of norisoprenoids.

The presence of these secondary metabolites indicates that Pandanus amaryllifolius has high antioxidant activity, so it contributes to its hepatoprotective activity by inhibiting oxidative stress that can cause inflammation, cardiovascular disease, degenerative diseases diabetes, cancer development, aging. Research conducted by Suryani et al. on pandan leaf ethanol extract (Pandanus amaryllifolius) and the fractionation process showed that the ethyl acetate fraction of pandan leaf ethanol extract had a higher reducing ability than ethanol extract. However, its DPPH radical scavenging power was higher. low with the calculation of EC50 between fractions of hexane, ethyl acetate, ethanol extract, and commercial vitamin E respectively $0.90 ; 8.66 ; 4.51$; and $11.76 \mathrm{mg} / \mathrm{mL}$, which indicates the ethyl acetate fraction of pandan leaf ethanol extract has the potential as a source of natural antioxidants that help wound healing. (Suryani, 2017; Ismail et al., 2017; Rahmi, 2021; Shameenii, A. et al., 2021). This study is also in line with research conducted by Safitri et al. (2020), showing that in wound healing, flavonoids also have an anti-inflammatory effect by inhibiting signals in microglia cells, resulting in impaired inducible nitric oxide synthase (iNOS) and decreased nitric oxide (NO) levels. ). This results in analgesic and neuroprotective effects so that pain in the skin affected by wound trauma is reduced. Besides that, flavonoids can also stimulate vascular endothelial cell growth factor (VEGF) in the angiogenesis process, which is very important in the healing process by stimulating growth factors. such as PDGF, EGF, TGF- $\beta$, and FGF.

The difference in this study is the type of plant used, namely pandanus leaf plants were used, while the study of Safitri et al. (2021) used red spinach leaves.In addition, fragrant pandan leaves also have antimicrobial activity (MICs range $30-125 \mathrm{~g} / \mathrm{mL}$ ), especially against Porphyromonas gingivalis, Streptococcus mutans, Streptococcus sanguinis, and Streptococcus salivarius, which is strongly influenced by the total content of flavonoids and phenols with a total value of phenol $57.25 \pm 0.02 \mathrm{mg} / \mathrm{g}$ and IC50 $110 \pm 36.42$ were examined by the DPPH method.The anti-inflammatory, antioxidant and antimicrobial 
content in 50\% pandan leaves extract also showed accelerated healing in post-gingivectomy wound models in Wistar rats. It can increase the number of blood vessels with p-value $=0.000(\mathrm{p}<0.05)$ through examination of histological preparations with staining. Hematoxylin-eosin compared with $2 \% \mathrm{CMC}-\mathrm{Na}$ and Ivoclar gel. The increase in the number of new blood vessels is strongly influenced by growth factors such as PDGF, VEGF, and bFGF, as well as endothelial progenitor cells (Nofikasari, 2016). In line with this study, rats that received routine treatment with pandan leaf extract ointment with one of the wound healing parameters, namely collagen thickness, and angiogenesis, showed significant differences compared to the untreated group.

The use of pandan leaves in solid preparations (ointments, creams, gels) in other studies has also begun to be carried out; this aims to maintain its effectiveness and facilitate its application to various types of wounds with various dosage forms in the medical world, one of which is in research that observes the role of the dosage form. Fragrant pandan leaf gel with $70 \%$ ethanol extract on burn healing, the formula with $12.5 \%$ fragrant pandan leaves resulted in the most effective percentage of burn healing, 99.33\%, with a healing time of 16 days. The preparation of pandan leaf ethanol extract gel based on Hydroxy Propyl Methyl Cellulose showed the results of physical stability tests, including organoleptic, $\mathrm{pH}$, and dispersibility tests. This shows that the manufacture of solid preparations of pandan leaf extract gives good results. (Dewanti et al., 2020). However, another study tested the effectiveness by using an ointment base preparation on fragrant pandan leaves on male white mice with a concentration of $5 \%, 7.5 \%, 10 \%$. It shows better results at 13 days with a healing percentage of up to $100 \%$ at a $10 \%$ ointment concentration. In research, Rini et al. (2018) also found the content of saponins, flavonoids, alkaloids, tannins, and polyphenols. The flavonoid content of pandan leaves can also accelerate the wound healing process by inhibiting the inflammatory process.

Flavonoids inhibit wound inflammation in several ways, namely by inhibiting capillary permeability, inhibiting arachidonic acid metabolism so that prostaglandin production is reduced, inhibiting the secretion of enzymes in lysosomes, which are inflammatory mediators inhibiting mediators of inflammatory cell proliferation in wounds. So in this study, the ointment formulation was the choice compared to other topical formulations. In line with this study, the effectiveness of burn healing can also be assessed from the acceleration of angiogenesis regeneration, collagen fiber thickness, and wound contraction. (Rini et al, 2018; Rokhmah et al, 2021). Analysis of pandan leaves with ethanol-water extract of leaves by immersion, or microwave-assisted extraction (MAE) method showed the presence of phenolic and flavonoid compounds and have antioxidant activity. Pandan leaf extract contains free amino acids such as aspartic acid, serine, lactic acid glutamate, glycine, histidine, arginine, threonine, alanine, proline, tyrosine, valine, lysine, isoleucine, leucine and phenylalanine, glucose, and fructose which may be precursors of ACPY (2-acetyl-1pyrroline) and may play an essential role In another study, pandan extract showed good potential for bioactive compounds such as Pandan leaves containing several bioactive compounds of carotenoids, flavonoids such as catechins, naringin, kaempferol, rutin, epicatechin, myricetin, luteolin, quercetin and phenolic acids including gallic acid, cinnamic acid, ferulic acid, caffeic acid Leaf extract (Pandanus amaryllifolius) showed antioxidant activity and which is higher than the extract in the root of Pandanus amaryllifolius, thus pandan leaf extract has the potential as a suitable natural antioxidant, which can serve as an alternative to synthetic antioxidants used in topical emulsions of plant extracts.

Pandanus amaryllifolius to obtain more optimal antioxidant activity to accelerate and affect wound healing which includes wound contraction, formation of new blood vessels, and density of collagen fibers formulated in topical preparations in the form of ointment formulations. (Silalahi, 2018; Bhuyan \& Sonowal, 2021).Tannins contained in Pandanus amaryllifolius are very complex organic compounds that are amorphous, have a phenolic hydroxyl group, and can form stable cross-links with proteins and biopolymers. A study conducted by Dewi et al. (2019) showed that the optimal tannin content in pandan (Pandanus amaryllifolius) leaves obtained using distilled water was 60 minutes. Phytochemical screening of P. amaryllifolius extract showed the presence of tannins, alkaloids, saponins, terpenoids, and flavonoids except for pholabanin and cardiac glycosides. The total phenolic content (TPC) was $35.99 \pm 0.04 \mathrm{mg} \mathrm{GAE} / \mathrm{g}$ and the total flavonoid content (TFC) was $59.96 \pm 0.013 \mathrm{mg} \mathrm{CAE} / \mathrm{g}$ extract. The tannin content in the ethanolic extract of fragrant pandan leaves is useful as an astringent that causes shrinkage of skin pores, stops exudate 
and light bleeding so that it can cover wounds, and prevent bleeding in wounds that inhibit the inflammatory process (Ambreen \& Mirza, 2020; Shameenii, 2004). A., et al, 2021; Rokhmah et al, 2021; Dewi et al, 2019).

\section{CONCLUSION}

Phytochemical test of Pandan Wangi Ethanol extract, which is made, contains chemical compounds in alkaloids, saponins, flavonoids, tannins, triterpenoids and steroids, and glycosides. The administration of Pandan Wangi Ethanol extract ointment is effective in healing incisional wounds. This can be seen from the significant difference in wound contraction on the 16 th day, where the P-value $=<0.05$. This indicates a significant difference in the healing of the rat incision wound. On the density of collagen, There was a significant difference in the group given the $10 \%, 20 \%$, and $30 \%$ ethanol extract of pandan fragrance ointment against the group that was only given the ointment base. This can be seen from the value of $p=$ $<0.05$, which means that there is an ointment of fragrant pandan extract that is effective in forming collagen in rat incision wounds. There was also a significant difference in the formation of new blood vessels in the group given the $10 \%, 20 \%$, and $30 \%$ ethanol extract of pandan fragrance ointment against the group that was only given the ointment base. This can be seen from the value of $p=<0.05$, which means that there is an effective pandan fragrance extract ointment in forming new blood vessels in the rat incision wound.

\section{REFERENCES}

[1] Aini R, Mardiyaningsih A. Pandan leaves extract (Pandanus amaryllifolius Roxb) as a food preservative. Jurnal Kedokteran dan Kesehatan Indonesia. 2016 Oct 17;7(4):166-73.

[2] Ambreen, Madieha, and Safdar Ali Mirza. "Evaluation of anti-inflammatory and wound healing potential of tannins isolated from leaf callus cultures of Achyranthes aspera and Ocimum basilicum." Pakistan journal of pharmaceutical sciences 33 (2020).

[3] Angkasa C, Angkasa A, Lister IN, Girsang E, Fachrial E. Effectiveness Test on Centella Asiatica Extract on Increasing Elasticity Level on Male Mus Musculus. American Scientific Research Journal for Engineering, Technology, and Sciences. 2019 Aug 10;58(1).

[4] Asrade S, Geta M, Fentahun E (2020). "In Vivo Evaluation of Wound Healing and Anti-Inflammatory Activity of 80\% Etanol Crude Flower Extract of Hagenia abyssinica (Bruce) J.F. Gmel in Mice". Volume 2020, DOI: https://doi.org/10.1155/2020/9645792.

[5] Bhuyan, B., \& Sonowal, R. (2021). AN OVERVIEW OF Pandanus amaryllifolius Roxb. ex Lindl. AND ITS POTENTIAL IMPACT ON HEALTH. Current Trends in Pharmaceutical Research, 8(1).

[6] Bouyahya, A. et al. (2016) 'Determination of Phenolic Contents, Antioxidant and Antibacterial Activities of Strawberry Tree (Arbutus unedo L.) Leaf Extracts,' British Biotechnology Journal, 14(3), pp. 1-10. DOI: $10.9734 / \mathrm{bbj} / 2016 / 26488$.

[7] Dewanti AP, Azzahra F. Uji Karakteristik Sediaan Gel Ekstrak Etanol Daun Pandan (Pandanus Amaryllifolius Roxb.) Dengan Basis Hydroxy Propyl Methyl Cellulose (Hpmc). AFAMEDIS. 2020 Nov 13;1(2):31-41.

[8] Dewanti, N. I., \& Sofia, F. F. (2017). Review Artikel: Aktivitas Farmakologi Ekstrak Daun Pandan Wangi (Pandanus amaryllifolius Roxb.). Farmaka Suplemen, 15(2), 186-194.

[9] Dewi, A. L., V. D. Siregar, and H. Kusumayanti. "Effect of Extraction Time on Tannin Antioxidant Level and Flavonoid on Pandan Wangi Leaf (Pandanusamary Trifolium Roxb) Using Hydrothermal Extractor." Journal of Physics: Conference Series. Vol. 1295. No. 1. IOP Publishing, 2019.

[10] Ersel M, Uyanikgil Y, Akarca FK, Ozcete E, Altunci YA, Karabey F, Cavusoglu T, Meral A, Yigitturk G, Cetin EO. Effects of silk sericin on incision wound healing in a dorsal skin flap wound healing rat model. Medical Science Monitor: International Medical Journal of Experimental and Clinical Research. 2016;22:1064.

[11] Ismail, H. F., Hashim, Z., Soon, W. T., Ab Rahman, N. S., Zainudin, A. N., \& Majid, F. A. A. (2017). Comparative study of herbal plants on the phenolic and flavonoid content, antioxidant activities, and toxicity on cells and zebrafish embryo. Journal of traditional and complementary medicine, 7(4), 452-465

[12] Jeong W, Yang CE, Roh TS, Kim JH, Lee JH, Lee WJ. Scar prevention and enhanced wound healing induced by polydeoxyribonucleotide in a rat incisional wound-healing model. International journal of molecular sciences. 2017 Aug; 18(8):1698. 
[13] Lister IN, Amiruddin HL, Fachrial E, Girsang E. Anti-Aging Effectiveness of Avocado Peel Extract Ointment (Persea Americana Mill.) against Hydration, Collagen, and Elasticity Levels in Wistar Rat. Journal of Pharmaceutical Research International. 2021 Jun 22:173-84.

[14] Lolok, N., Yuliastri, W. O., \& Abdillah, F. A. (2020). Efek Antidiabetes Kombinasi Ekstrak Etanol Daun Pandan Wangi (Pandanus amaryllifolius Roxb.) Dan Daun Salam (Syzygium polyanthum Wight.) Pada Tikus Putih Dengan Metode Induksi Aloksan. Jurnal Mandala Pharmacon Indonesia, 6(01), 13-29.

[15] Louis, H. et al. (2017) 'Determination of total phenolic content and some selected metals in extracts of Moringa oleifera, Cassia tora, Ocimum gratissimum, Vernonia Baldwin and ...', World News of Natural ..., 11, pp. 1118.

[16] Nagar HK, Srivastava AK, Srivastava R, Kurmi ML, Chandel HS, Ranawat MS. Pharmacological investigation of the wound healing activity of Cestrum nocturnum (L.) ointment in Wistar albino rats. Journal of Pharmaceutics. 2016;2016.

[17] Nanda Y, Salim MN, Iskandar CD. Histopatologi Kulit Mencit (Mus musculus) Fase Remodeling Pada Penyembuhan Luka Sayat dengan Salep Getah Jarak Pagar (Jatropha curcas Linn). Jurnal Ilmiah Mahasiswa Veteriner. 2017 Oct 12;1(4):780-7.

[18] Nasiri E, Hosseinimehr SJ, Azadbakht M, Akbari J, Enayati-Fard R, Azizi S, et al. The healing effect of arnebia euchroma ointment versus silver sulfadiazine on burn wounds in Rat. World J Plastic Surg. 2015;4(2):134-44.

[19] Ningrum, Andriati \& nguyen minh, Nhut \& Schreiner, Matthias. (2015). Carotenoids and Norisoprenoids as Carotenoid Degradation Products in Pandan Leaves ( Pandanus amaryllifolius Roxb.). International Journal of Food Properties. 18. 1905-1914. 10.1080/10942912.2014.971186.

[20] Nofikasari I, Rufaida A, Aqmarina CD, Failasofia F, Fauzia AR, Handajani J. Efek aplikasi topikal gel ekstrak pandan wangi terhadap penyembuhan luka gingiva. Majalah Kedokteran Gigi Indonesia. 2016;2(2):53-9.

[21] Rodrigues M, Kosaric N, Bonham CA, Gurtner GC. Wound healing: a cellular perspective. Physiological reviews. 2019 Jan 1;99(1):665-706.

[22] Rokhmah, N. N., Yulianita, Y., \& Putra, R. A. (2021). EFEKTIVITAS GEL DAUN PANDAN WANGI SEBAGAI OBAT LUKA BAKAR PADA TIKUS PUTIH JANTAN. Pharmacoscript, 4(2), 131-140.

[23] Safitri, T. O., Nasution, A. N., Ginting, C. N., \& Girsang, E. (2021, July). The Effectiveness of Red Spinach Extract Ointment (Amaranthus tricolor L.) against Healing Second Degree Burns in Wistar Rat. In 2021 IEEE International Conference on Health, Instrumentation \& Measurement, and Natural Sciences (InHeNce) (pp. 16). IEEE.

[24] Saifudin M, Herbani M, Andriana D. PERBANDINGAN EFEK PERASAN DAGING DAUN LIDAH BUAYA (Aloe vera L.) DAN POVIDONE IODINE TERHADAP EKSPRESI VEGF DAN JUMLAH LUMEN PEMBULUH DARAH TIKUS WISTAR DENGAN LUKA SAYAT. Jurnal Kedokteran Komunitas. 2020 Jan $30 ; 8(1)$.

[25] Shakya P, Sharma AK, Kumar N, Vellachi R, Mathew DD, Dubey P, et al. Bubaline cholecyst derived extracellular matrix for reconstruction of full-thickness skin wounds in rats. Scientifica. 2016;2(1):1-13.

[26] Shamanic, A. et al. "Hepatoprotective effects of Pandanus amaryllifolius against carbon tetrachloride (CC14) induced toxicity: A biochemical and histopathological study." Arabian Journal of Chemistry 14.10 (2021): 103390

[27] Silalahi M. Pandanus amaryllifolius Roxb (Pemanfaatan dan potensinya sebagai pengawet makanan). Jurnal Pro Life. 2018;5(3):626-36.

[28] Sugihartini N, Nuryanti E. Formulasi Krim Ekstrak Daun Kelor (Moringa oleifera) sebagai Sediaan Antiaging (Formulation Cream of Extract Moringa oleifera Leave as Antiaging). Berkala Ilmu Kesehatan Kulit Dan Kelamin. 2017;29(1):1-7.

[29] Suryani CL, Murti ST, Ardiyan A, Setyowati A. Aktivitas Antioksidan Ekstrak Etanol Daun Pandan (Pandanus amaryllifolius) dan Fraksi-Fraksinya. Agritech. 2017;37(3):271-9.

[30] Suwannakul S, Chaibenjawong P, Suwannakul S. Antioxidant Anti-Cancer and Antimicrobial Activities of Ethanol Pandanus amaryllifolius Roxb. leaf extract (In Vitro)-A potential medical application. Journal of International Dental \& Medical 